\title{
Changing family patterns from rural to urban and living in the in-between: A public practical theological responsive ministerial approach in Africa
}

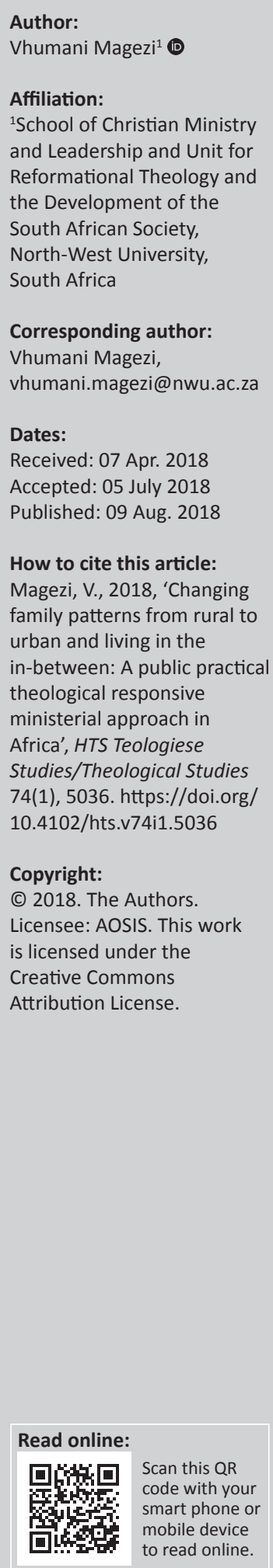

African people and their families find themselves in a situation of tension because of their transition from rural to urban life. This tension has created a third family type, namely emerging families. The emerging families are characterised by a sense of life being under a constant strain to meet individual needs and at the same time the expected needs of the extended family. In such a situation, an individual gets sandwiched in a space of confusion, trapped in an in-between space where one is unsure whether to stick to traditional rural values and norms amidst the challenges of the reality of inadequate financial resources to support extended family members. Thus, one's life space in Africa should be considered as being in a state of shifting fluidity. The outcome is an emerging and negotiated family where new arrangements are developing. In response, pastoral care should take a public dimension. Pastoral care should develop an analytic framework as well as a public practical theological ministerial approach that responds to these changing family patterns. It is proposed that a responsive public pastoral care approach could perform three tasks: preventive, mitigatory and maintenance pastoral care.

\section{Introduction}

Industrialisation and urbanisation have been identified as forces that have disrupted family setup in Africa and other parts of the world. Discussions on family in Africa have overlooked the complexity of the transition of families from rural to urban by analysing family transitions in binary terms where families in cities tend to be simply juxtaposed with traditional rural extended family and comparisons drawn. This approach overlooks the fact that families are not static. There is a phenomenon of new emerging family patterns in Africa that has been overlooked. Africa of the precolonial era and Africa of 2018 are different and so are the family patterns. The question for theology is: how could such changes in family patterns be understood and responsive ministerial designs be developed? This calls for an examination of the 'family in Africa' and the changing patterns with a view to developing responsive public practical and pastoral responses, which is the focus of this article.

\section{Synoptic view of family within transition from rural to urban}

Family is a fundamental building block of society (Thornton 2005:4). Scholars such as Haralambos and Holborn (2004:466-500) and many others have classified family structures into the following categories: (1) a nuclear family, where there is a sharing of two generations of family members under the same roof; (2) an extended family, where three or more generations live in the same household (or very close proximity); (3) a single parent family, where the family structure involves a single person plus dependent children; and (4) finally, a reconstituted family, sometimes called 'step-families', where the family unit is one of the consequences of high rates of divorce and remarriage (or cohabitation).

Sociologists have studied families from a number of perspectives. These include functionalist, conflict, symbolic interactionist, feminist and postmodern perspectives (Essays, UK 2013:1-3). ${ }^{1}$ From a functionalist perspective, the family unit has been viewed as a construct that fulfils important functions and keeps society running smoothly. The conflict perspective views the family as a vehicle for maintaining patriarchy (gender inequality) and social inequality in society.

1.The strengths and weaknesses of these perspectives have been widely discussed and analysed in literature. Thus, notwithstanding the utility of these perspectives as analytic frameworks, it is outside the scope of this paper to discuss these frameworks in detail. 
The symbolic interactionist perspective views the family as a site of social reproduction, where meanings are negotiated and maintained by family members. At the same time, the feminist perspective views the family as a historical institution that has maintained and perpetuated sexual inequalities. The postmodernistic approach argues that in many societies there are diverse and multicultural types of families where members within these units are free to make their own life choices as to how, what and where they live, work and socialise within society (Essays, UK 2013:1-3; Haralambos \& Holborn 2004:466-500).

One area within family studies that has remained evolving and warranting ongoing discussion and analysis is the effects of urbanisation and industrialisation. Puschmann and Solli (2014) observed that the debate on the impact of urbanisation and industrialisation on family configurations has been inconclusive. They summarised the hanging debate as follows:

From a functionalist point of view, sociologists believed that urbanization, migration and nuclearization went hand in hand, as nuclear families were more geographically mobile than more complex family types. At the same time, scholars of the Chicago School of Sociology believed that the adaptation process of ruralto-urban migrants was highly problematic, and that migrants ended up on the edge of urban society, because they lacked a social network. However, studies by Anderson (1971), Hareven (1982) and Janssens (1993) suggest that extended families persisted in the urban industrial environment, that extended families offered the best shelter for rural-to-urban migrants in industrial cities, and that they facilitated urban integration. At the same time, other studies suggest that integration was not as difficult as has been suggested by the Chicago School of Sociology. (p. 6)

While the studies that led to Puschmann and Solli's (2014:6) aforementioned conclusion were not based on family studies in Africa, there are clear similarities that can be observed among families in Africa. The emergence of new family dynamics and family forms seems not to have been given considerable attention (Russell 2003:153-176). In view of this situation, it is important to examine the present situation of families without necessarily focusing on their history, but rather focusing on the current state of families as a result of the urbanisation process. This is the task of the subsequent section.

\section{The present situation of families}

Currently, global families, including African families, have been undergoing alterations and new configurations because of industrialisation and urbanisation (Bigombe and Khadiagala 1990:10-15; Chirozva, Mubaya \& Mukamuri n.d.:4-24; Ssemogerere 2011:5-7). Family changes resulting from urbanisation have been a subject of discussion for a considerable length of time. Ruggles (2012:423-441) noted that Frédéric Le Play $(1855 ; 1872)$ was the first scholar who investigated shifts in family configurations in a systematic way, and he was one of the pioneering social scientists who argued that society was changing under the influence of urbanisation and industrialisation. The traction in family and urbanisation studies has been a result of the recognition that, as Thornton (2005:4) noted, families are the true building blocks of society. Puschmann and Solli (2014:1) observed that Le Play distinguished families by classifying them into three categories, namely patriarchal families (called 'extended families' today), stem families and unstable families (nowadays referred to as 'nuclear'). Patriarchal families are widespread in non-Western countries. In such families, newly married sons live with their parents and under the authority of the head of the household. For instance, in Africa, family capital was undivided and maintenance of the family line was guaranteed through transmission of customs and tradition from one generation to the next (Bigombe \& Khadiagala 1990:10-15; Chirozva et al. n.d.:4-24; Ssemogerere 2011:5-7). Stem families share most of their characteristics with patriarchal families but differ regarding their system, where parents choose one of the children as their successor, usually the oldest son. Stem families are found in many parts of Europe. Unstable families, which were criticised by Le Play for their moral decay, are found among the working classes in the urban industrial areas of the Western world.

In the typical patriarchal families that are characteristic of many parts of rural Africa, values and norms are passed from one generation to the next through elders. Russell (2003:153) and Ssemogerere (2011:5-7) noted that in rural areas of Southern Africa, strongly enunciated rules about kin, responsibility and co-residence are passed from the elderly to younger generations. These rules of kinship were elaborated to become the political backbone of society itself. When individuals migrate to cities and find a job, the instructions, norms and values received from the elders are kept at heart. They have to be obeyed. One cannot just abandon who they are because they are in a city. To abandon these values and norms is to deny yourself as an extension of the rural community.

However, the desire to maintain one's values is severely challenged by the reality of living in cities. Russell (2003:154) observed that the challenges of living in the cities include the enticements that the capitalist industrial society seems to offer, such as jobs, money and independence, while at the same time being conscious that the system offers meagre resources despite its bounty. Thus, people are caught up in trying to assert and preserve their cultural distinctiveness and yet at the same time wanting to be an invisible assimilated part of the brave new world. The situation painted by Russell (2003:154) summarises the tension in many African people's transition from rural to urban. The urban system itself has some attractions that put one in direct conflict with traditional rural practices. Russell (2003) further reported that the urban black elite show every sign of acculturation to Western life:

Family and household practices are pressed into the Western mould by, for example, the provision in towns of nuclear-familysized houses, each with its own nuclear family-sized yard. Furthermore, hundreds of packed churches are superintended by indoctrinated pastors inveighed against polygamy, levirate, premarital sex, and, above all, against the acknowledgement of ancestral spirits, those capricious powerful patrons of the older order. (p. 154) 
Russell (2003:155) added that in these urban spaces, European or Western fashions, house furniture and European tea parties, among other things, occupy a central position in the lives of many black African people.

Thus, an African person would be characterised by living in two worlds without fully belonging to either. On the one hand, one tries to live as a traditional African person who upholds traditional values, ethics and customs of relationality and communality. On the other hand, one has to live a life that suits urban and Western life practices. This creates a human being who is living a trapped life, which Magezi (2016a:83) described as 'living life in the in-between'. Unfortunately this life of tension and in-between has not been considerably examined in Africa. This lack of consideration of the present existential life space of many African people and families leaves a vacuum in the present understanding of African family challenges.

\section{Understanding the gap in family and urbanisation reflections in Africa}

Notably, the transition and disruption from patriarchal and stem families to unstable families in Africa was caused by many factors, but chief among them is urbanisation. The pride and honour of parents included passing on material resources, which was further complemented by passing on wisdom to children. This was important capital that was given to children. However, the rise of industrialisation meant that children could get jobs in the cities and be financially independent. Children's independence resulted in the decline of families' ability to pass down capital from one generation to the next because of wage labour. The capital that parents used to pass on, such as wisdom and wise counsel and resources in some cases, were replaced by wage labour, as people could now survive on their wages. This meant the power and authority of parents were weakened.

Puschmann and Solli (2014:2) explained that many of the founding fathers of sociology, including Emile Durkheim, Ferdinand Tonnies, Georg Simmel and Max Weber, stressed that because of urbanisation and industrialisation, a transition from multigenerational to nuclear families took place in 19thand early 20th-century Europe. These scholars draw a diametric distinction between preindustrial rural and urban industrial societies. Preindustrial rural societies were characterised by extended families and close social and economic relations that continued to exist among family members throughout the individual's life course. Jackson (1997) added that religion, as well as customs and habits, regulated social life in the village, and solidarity among villagers was essential.

As people transitioned to urban industrial societies, families were altered to nuclear families, where kinship weakened. There was weak communication with kin members and increased physical distance among kin members as members migrated from rural to urban settings, where economic needs took precedence. Cities were places where life was faster, more organised and more bureaucratic. Life was characterised by anonymity, chaos, loneliness and confusion. Puschmann and Solli (2014:2) added that solidarity and social control were weaker in cities than in villages and the formation of social networks was harder in the urban environment. City life was more individualistic and the construction of a personal identity became necessary. Furthermore, in the cities there was less influence of religion, and religious customs and habits declined (Liang 2008).

Within Africa, the destruction of parents' capital, urban freedoms, the need for labour in the cities and the enticements that come with being in the city and earning income created a new human being with new ways of doing things. The initiation and inculturation of urban life created a gap between rural and urban individuals. This emerging new state of being is characterised by tension. This is to say, many African people are caught up in an urban-rural life tension, which Magezi (2006:505-521) called an oscillation between traditional life and urban life. This oscillation entails one's attempts to have urban life coexist with traditional community and rural life norms on various fronts that include physical, cultural, religious and psychospiritual levels. The tension interplays with persisting confusion regarding one's identity as one is sandwiched between two social life systems. One is unclear, uncertain and anxious to let go of traditional values to embrace the capitalist values that are embedded in urbanisation and industrialisation. This tension between desiring to escape and conform results in new coping mechanisms of living life in a new space in between urban and rural. It's a confusing life system that comprises dissonance as one is unsure about how to proceed with life, frustration by failing to fulfil ones' expected roles to self and community, a sense of betrayal of kin and a struggle for identity in the context of the urban space.

Sadly, while African people are caught in this in-between space, some African contemporary scholars such as Baloyi (2014), Wasike and Waruta (2000), Waruta and Kinoti (1994) and Mbiti (1969), just to mention a few, in their writings refer to African people and families in ways that seem to suggest a clear distinction of life patterns from white people. On the one hand, they project African families in a way that is reminiscent of traditional village life practices despite the effects of urbanisation. In doing so, they adopt an apologetic stance to defend African cultural practices. On the other hand, scholars such as Magezi (2017) and Bowers (2009) present some African people as disoriented because of urbanisation. In this disorientation, they seek to reclaim their traditional heritage. Magezi (2016b), and Bowers (2009) argue that some scholars have adopted a progressive stance by focusing on present Africa, acknowledging the reality of a changed Africa in terms of family patterns and practices.

Given the aforementioned discussions, it should be maintained that the current situation of Africa after urbanisation and industrialisation has altered African families to resemble some elements of Western nuclear families but at 
the same time holds onto traditional African practices. In an insightful empirical research article report, 'Are urban black families nuclear? A comparative study of black and white South African family norms', where the sample was drawn from Pretoria (Mamelodi), Durban (KwaMashu), East London (Gompo) and Cape Town (Khayelitsha and Gugulethu), Russell (2003) observed that:

Urban blacks responded to some statements like rural blacks but to others like urban whites. In matters of family and kinship, urban blacks are still influenced by a distinctive African cultural approach to kinship as well as adapting their views in light of new urban experiences. (p. 153)

This indicates that African people are caught up in an inbetween space, some sort of trap, a transition space that is somewhat characterised by confusion. These developments in new family patterns challenge one to consider African families in terms of transition. This transition is more of a liminal space where the families are attempting to let go of traditional African ways to embrace urban life but not completely. 'Liminality' refers to a period of transition from one stable situation to another (Magezi 2017:115). ${ }^{2}$ The situation indicates a range of possibilities for family survival strategies. It challenges families to accept a multiplicity of social relations within and across households. It discourages a static view of family in changing contexts but encourages rather an evolving one. Hence, the questions that emerge from this discussion are as follows: in view of the transition in families, how can families be understood in contemporary Africa? How could this understanding assist in formulating and developing a responsive practical theological approach that ensures an effective pastoral care ministry within African contexts where traditional family systems are changing? How could pastoral care become public in nature to respond to the dynamics of the emerging family systems and patterns?

\section{Towards an alternative understanding of the current African family situation and a responsive public practical theology Towards understanding emerging families in Africa}

The changes in African family dynamics need to be understood and interpreted within the context of emerging patterns and changes. Some African authors (Chirozva et al. n.d.:4-24; Ssemogerere 2011:5-7) juxtapose precolonial and present Africa with the effects of industrialisation and urbanisation to draw comparisons. These comparisons tend to focus on these two periods without recognising the emergence of a third pattern of family life. Kertzer and Hogan's (1989) observation of the complexity of the transition of families from rural to urban is an important aspect that is worth noting. Some African scholars tend to analyse family transitions in binary terms. The situation of families in cities tends to be simply juxtaposed with traditional rural extended 2.For a discussion on liminality, see Magezi (2017:11-122). family in order to draw comparisons. This approach overlooks the fact that families are not static and homogenous and they don't simply change from one shape or form to another instantly. Rather, they undergo a continuum of changes. Puschmann and Solli (2014:4) rightly argued that because families and households evolve over a period of time, it is important that studies in families adopt a longitudinal approach rather than a simple cross-sectional approach. For instance, a family might be nuclear at a given moment in time when a census is taken but might turn into a multigenerational household at a later point. This may occur when one of the children marries and moves with the spouse into the parental household. Moreover, within an African context a family may seem nuclear when the parents are working but upon retrenchment or retirement they rejoin the rural extended family in the village.

In view of the aforementioned family dynamics, Kertzer and Hogan (1989) maintained that the relationship between family alternation and industrialisation is much more complex than expected. Laslett (1969:199-223) and Hajnal (1982:449-494) made significant contributions to the understanding of family changes, among other things fluidity in the understanding of family changes. Puschmann and Solli (2014:4) noted that there are other alternative explanations such as the attractiveness that is associated with urban life. Thus, urban life practices cannot be simplistically explained. However, the question that arises is: what framework can we adopt to understand current families in Africa? While theoretical attempts to explain family transition to urban life have been considerably refuted and counter explanations to account for nuclear families prior to urbanisation and industrialisation equally discredited, a vacuum exists. Janssens (1993) was concerned that Laslett successfully dismantled the sociological paradigm that industrialisation and urbanisation had changed family life but did not replace it with any new theory. Theory formation is critical to understand and explain new trends in families within urban contexts.

A theory for understanding emerging families in Africa should account for the emerging new phenomenon of family. The existing tension among many black Africans in urban settings seems to have given rise to a new phenomenon of family. This phenomenon is about a newly emerging family and community system resulting from urbanisation. Russell's (2003:168) study revealed an anticipated gap between rural and urban people among his respondents. And yet, these responses do not strictly fit into the 'box' of typical rural or urban characteristics. In responding to the questions asked by Russell, urban blacks responded unlike both rural blacks and urban whites. Russell (2003:168) therefore posed a useful question and proceeded to provide an insightful response: 'Does this lend support to the assertion that urban blacks are experiencing a transition to a nuclear system? The dispassionate answer, based on this evidence, can only be a tentative "maybe"" (Russell 2003:168).

The situation observed by Russell suggests that many African people are caught in a space that they cannot control, a place 
of change and limited options. They are caught in a space of changing, if not changed, family situations. The traditional family life shaped around kinship and community is vanishing, if it has not already vanished, with the new life planned around employment and income because of its economic value. As a result, urban families are socialised to put themselves first, and much less the good and needs of the wider community. The result of this is a new family system resulting from urbanisation and the new set-up and configurations, which I call 'refamilying', referring to doing family differently because of emerging patterns. Russell (2003:169), citing other scholars such as Coleman (2001:81) and Beck and Beck-Gemschein (1995:145), described these developments and the emerging new family (i.e. refamilying) as having the following results:

The outcome is the negotiated family, the alternating family, the multiple family, new arrangements after divorce, remarriage, divorce again, new assortments from your, my, our children, our past and present families' as people repeatedly couple and recouple in the quest for meaning. Rules about who is or is not a member of your family are unclear (Coleman 2000:81). Underlying this phenomenon lies the capitalist market economy with its demand, not for nuclear families, but for unattached, mobile single persons. (Russell 2003:169)

In view of these changes, black families should be understood as being in a unique space. 'They too respond with a growing self-centredness, a growing hedonism, a growing sense that one should have to be responsible to nobody but oneself' (Russell 2003:170) and yet retain traditional rural features. At the same time, they are modern and urbanised in a distinctive way. Their distinction derives from their experiences and orientation. They 'retain their distinctiveness, which is rooted in a different past and a different set of inherited household practices and shaped by a different experience of history' (Russell 2003:170). Thus, convergence of urban and rural life styles should be seen as a long way off, and the shape of the emerging new domestic order uncertain. Black African families, despite being in urban centres, should be understood from the notion of descent. Although the cultural patterns are waning and changing, African people should be understood as being rooted in their root cultures. Notwithstanding the attractions to young people of urban life, such as independence and the authority that comes with financial power resulting from earnings, the equal opposing force of extended family glue continues to make a person live in the in-between, that is, suspended between urban and traditional spaces.

A depiction of family transition from the traditional African family system to urban life as a result of industrialisation and the emerging new family patterns is summarised in Table 1. Table 1 summarises the changes and emerging patterns in material (physical) support, social support, spiritual support and emotional support.

The questions that could be posed, as already indicated earlier, are as follows: How could the understanding of family assist in formulating and developing a responsive practical theological approach that ensures an effective pastoral care ministry within African contexts, where traditional family systems are changing? How could pastoral care become public in nature to respond to the dynamics of the emerging family systems and patterns?

\section{Towards a proposal for a diagnostic and hermeneutical framework to understand changing family situations}

The intersection of practical and public theology is an important nexus for public practical ministries. Practical theology is an approach that focuses on ensuring that theology is useful and relevant to everyday concerns, while public theology focuses on the need for theology to interact with the public issues of contemporary society. Pastoral care is concerned with providing care and support to people in pain and anxiety, including any other life situation. Clearly, practical theology is interconnected with public theology. Practical theology includes a public dimension in its work (Osmer \& Schweitzer 2003:215). However, Dreyer (2004:919) rightly argued that not all practical theology is public theology, in other words aimed at a non-ecclesial general audience. Practical theology is also theology for the church, that is, for a Christian audience, and is also theology for an academic audience. Dreyer (2004:919-920) added that the vision of practical theology should broaden to include the context of everyday life on a local, national and global level. Osmer and Schweitzer (2003:218) usefully explained that the task of public practical theology is discerned in three ways. Firstly, it is about ensuring that the public is one of the

TABLE 1: Summary characteristics of family life spaces.

\begin{tabular}{|c|c|c|c|}
\hline Defining feature & Rural family life (A) & Urban family life (B) & Emerging (new) family life (C) \\
\hline Physical support & $\begin{array}{l}\text { - Shared resources. } \\
\text { - Practical help in times of need. }\end{array}$ & $\begin{array}{l}\text { - Depend on individual financial resources, very } \\
\text { little practical support from neighbours. } \\
\text { - Support relatives and rural families. }\end{array}$ & $\begin{array}{l}\text { - Depend on individual resources but with } \\
\text { supplementary support in crisis. } \\
\text { - Physically support relatives when resources } \\
\text { permit. }\end{array}$ \\
\hline Social support & $\begin{array}{l}\text { - Close connection with extended family } \\
\text { members. } \\
\text { - Problems are jointly addressed as a community. } \\
\text { - Geographical location occupied by relatives. }\end{array}$ & $\begin{array}{l}\text { - Alone and residential home. } \\
\text { - Need to develop new connections and establish } \\
\text { new community. } \\
\text { - New community not based on blood. }\end{array}$ & $\begin{array}{l}\text { - Alone in residential area but with periodic } \\
\text { relative visits. } \\
\text { - Maintenance of rural-urban family connections. } \\
\text { - Occasional participation in social function. }\end{array}$ \\
\hline Spiritual support & $\begin{array}{l}\text { - Shared rituals. } \\
\text { - Shared ancestry. } \\
\text { - Respect for spiritual norms and values. } \\
\text { Protection by spirits and ancestors. }\end{array}$ & $\begin{array}{l}\text { - Continue with spiritual relationship with } \\
\text { ancestry. } \\
\text { - Protection by spirits and ancestors. } \\
\text { - Compliance with spiritual forces. }\end{array}$ & $\begin{array}{l}\text { - Expectation to uphold spiritual and ancestral } \\
\text { rituals. } \\
\text { Protection by spirits and ancestors (nominal or } \\
\text { strong compliance). }\end{array}$ \\
\hline Emotional support & $\begin{array}{l}\text { - Community is present for emotional catharsis. } \\
\text { - Emotions are expected to be shared by the } \\
\text { community. } \\
\text { - Pain and emotions are overcome by a sense of } \\
\text { shared problems. }\end{array}$ & $\begin{array}{l}\text { - Loss of significance. } \\
\text { - Loneliness. } \\
\text { Stress because of urban life demands. }\end{array}$ & $\begin{array}{l}\text { - Tension and confusion. } \\
\text { - Between the selfish ' } l \text { ' and the extended } \\
\text { family 'we'. } \\
\text { - Pain is addressed through a mixture of Western } \\
\text { and traditional African approaches. }\end{array}$ \\
\hline
\end{tabular}


audiences of practical theology. Secondly, it is to ensure that practical theology includes everyday concerns and issues in its reflection. Thirdly, practical theology should facilitate a dialogue between theology and contemporary culture. In linking public theology and pastoral care, Koppel (2015) maintained that:

Practising public theology asks that pastoral care practitioners and theologians take seriously and engage mindfully with issues that concern groups of people and whole populations, rather than individual persons in isolation. Framing pastoral care ministries, education, and institutions through this larger social lens helps theorists and practitioners to refine methods and purposes for our common work. (p. 151)

Thus, one legitimate way of approaching issues affecting society such as family is to approach them from the intersection of public theology, practical theology and pastoral care. Further, to the established link between these three approaches, many other scholars have expressed the value of such an approach. Vanhoozer and Strachan (2015:16-17), in The Pastor as Public Theologian, advised that the pastor should perform three roles. The pastor is a public figure: he or she embodies care and concern and expresses readiness and willingness to act on social needs rather than being mute and indifferent. Miller-McLemore (2005), in her essay 'Pastoral theology and public theology', noted the developments regarding the movement of pastoral care to public theology because of (1) the concern about the silence of mainstream Christianity on key social issues and (2) awareness of the limitations of pastoral focus on the individual alone. Gathogo (2007:101) argues from an African Reconstruction Theology perspective and maintains that in African Reconstruction Theology, pastoral care 'is pastoral in that it seeks to restore and address the challenges experienced in many African communities'. Louw $(2008,2014)$ locates practical theology and pastoral care as holistic life care. He argues that pastoral care should be life care by caring for people during their existential challenges.

Despite the value of intersecting public and practical theology for effective ministerial design, the challenge lies in translation of the Christian vision to the wider society (De Villiers 2005:530). There is need to develop a language and conversation as well as operational praxis that addresses societal issues that the public faces. Practical theology and public theology should assist with language and design (Dreyer 2011:3; Dreyer \& Pieterse 2010:6). Thus, to proceed from theory to praxis as well as ministerial design, it is the task of public practical theology to develop public and social responsive ministries that are theologically grounded. This calls for practical theology to imagine innovative ways of engaging life issues. Practical theology includes imagination (Cahalan \& Mikoski 2014:3). Thus, a model for developing a responsive family ministry in changing contexts should be imagined. The directional movements within family patterns are not unidirectional (see Figure 1).

People in rural areas (family life A) are attracted by urban life (family life B) and move (directional shift 1) to urban areas.

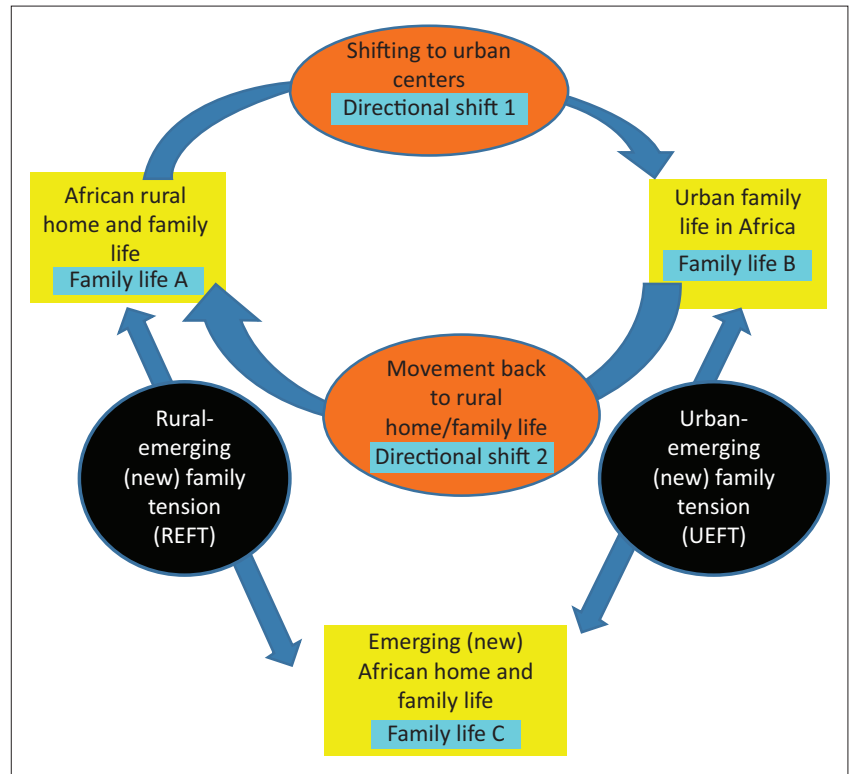

FIGURE 1: Directional movements in changing family patterns.

This movement creates positive and negative experiences. Positively, the movement creates excitement about prospects of having income. It creates anticipation and the promise of a better life. Hope, enthusiasm and optimism are generated. Negatively, there is anxiety and uncertainty about the new environment. Upon settling in the cities and being employed or engaging in whatever activities, these people remain connected to their rural roots.

The connection with rural roots occurs through communication and physical travelling (directional shift 2). The movement back from urban to rural has its positives and negatives. Positively, this movement enables one to physically reconnect with kin and enables physical contribution to family needs. Furthermore, this return movement comes with power and authority, as one is viewed as enlightened and now a provider. By making family contributions one's sense of worth, significance and benevolence is cultivated. On the negative side, this movement resembles a split of resources (especially financial) between the individual in the city and the many family members in the rural places. This causes a burden to support and sustain extended families. Unmet expectations resulting from inadequate resources trigger a sense of failure and betrayal of one's family as family members look up to the individual.

The efforts to cope with this challenging family situation and dynamics result in the emergence of a third type of family or individual (family life C). These family spaces are characterised by tension from two fronts. On the one hand there is a pull towards traditional rural customs and practices, that is, rural emerging family tension. This causes confusion, uncertainty and dissonance. As well, it is characterised by desire to break away from traditional rural family patterns, norms and values to embrace new family patterns and practices ushered in by modernity in urban life. The person is challenged by the question: what should I leave behind in my traditional rural life and what should I take with me? On the 
other hand, there is urban pull with its enticements and privileges, which causes an urban emerging (new) family tension. This is characterised by the desire to embrace urban life fully but at the same time wanting to retain something of their traditional values, norms and practices. Here, one is alone but with periodic visits from relatives, works hard to maintain rural-urban family connections, occasionally participates in family social functions and spiritual support is divided between family and new experiences. Tension and confusion between the selfish ' $\mathrm{I}$ ' and extended family 'we' are strong. Pain is addressed through a mixture of Western and African traditional approaches. One works hard to strike a delicate balance between meeting one's needs and fulfilling extended family responsibilities.

\section{Towards a public pastoral responsive ministry to changing family situations}

In view of the challenges experienced through the changes, pastoral care is challenged to be innovative. A pastoral care approach that responds to the needs of individuals and families at each stage of the change process is proposed. This approach entails three tasks: preventive, mitigatory and maintenance pastoral care.

The first task is preventive pastoral care. It is carried out with both individuals intending to migrate or move to different urban environments and the families remaining behind. It is practical care that is concerned with preparation, conscientisation, anticipation and shaping expectations. This includes raising awareness on the challenges that may arise and be encountered, as well as preventive counselling to moderate expectations and foster realism. This type of care can be done as a church enriching programme for parents and youth, including reaching other community structures such as guidance and counselling in schools. It touches on spiritual preparation and practical wisdom and advice.

The second task is mitigatory pastoral care. Mitigation is about responding to emerging needs. This is carried out with individuals when they arrive in new environments, for instance, when individuals move to urban areas from rural areas. This entails providing practical assistance and support to new individuals in an area. This includes linking with service providers, accompaniment and providing a supportive environment. This challenges pastors to develop competencies and social networking that enables them to be able to direct individuals to areas where they could be assisted. The needs of such people may vary from spiritual to physical. Some may require a place to worship while others may require practical assistance.

The third task is maintenance pastoral care. Maintenance is about developing congregational ministries that provide ongoing safety nets. It is about making church a second home for people. This includes establishing accommodating ministries of sustaining and nurturing. New people will be provided a spiritual home where their physical needs will also be addressed.

These pastoral interventions are both public in nature and spiritual. In their public expression, people are assisted through practical linking to services, assistance dealing with individual and family tensions and providing family and community to alleviate loneliness. This is not about turning a church into a non-governmental organisation but developing sacrificial and sensitive ministries that address the needs of people.

\section{Conclusion}

In conclusion, this article argued that African people and families are found in a situation of tension because of their transition from rural to urban life. This tension has created a third perspective to family, namely emerging families. The emerging family is characterised by a sense of life being under a constant strain to meet individual needs and the expected needs of the extended family. These people are sandwiched in a space of confusion, trapped in an inbetween space where they are unsure whether to stick to traditional rural values and norms amidst the challenges of the reality of inadequate financial resources to support extended family members' needs. In such a situation, one's life space in Africa should be considered as being in a state of shifting fluidity. The outcome is an emerging and negotiated family where new arrangements are developing. In this situation pastoral care should take a public dimension. Pastoral care should develop an analytic framework as well as a public practical theological ministerial approach that responds to these family changing patterns. To that end, it is proposed that a responsive public pastoral care approach could perform three tasks: preventive, mitigatory and maintenance pastoral care.

\section{Acknowledgements Competing interests}

The author declares that he has no financial or personal relationships which may have inappropriately influenced him in writing this article.

\section{References}

Baloyi, M.E., 2014, 'The impact of the extended family on one's marriage: An African study', Journal of theology for Southern Africa, 148, 8-32.

Beck, U. \& Beck-Gernschein, E., 1995, The normal chaos of love, Polity Press, Frankfurt.

Bigombe, B. \& Khadiagala, G.M., 1990, Major trends affecting families in Sub-Saharan Africa, viewed 14 April 2018, from http://www.un.org/esa/socdev/family/ Publications/mtbigombe

Bowers, P., 2009, 'Christian intellectual responsibilities in modern Africa', Africa Journal of Evangelical Theology 28, 91-114.

Cahalan, K.A. \& Mikoski, G.S. (eds.), 2014, Opening the field of practical theology: An introduction, Rowan and Littlefield, New York.

Chirozva Chaka, M.C.P. \& Mukamuri, B., n.d., The traditional African family in the age of globalization, viewed 14 April 2018, from http://www.beatafrica.org/comm

Coleman, D., 2001, 'Population and family', in A.H. Halsey (ed.), Twentieth century British social trends, pp. 27-93, Macmillan, Basingstoke.

De Villiers, E., 2005, 'The vocation of reformed ethicist in the present South African society', Scriptura 89(2), 521-535. 
Dreyer, J.S., 2011, 'Public theology and the translation imperative: A Ricoeurian perspective', HTS Teologiese Studies/Theology 67(3), Art. \#1157, 1-8. https://doi. perspective,
org/10.4102/hts. v67i3.1157

Dreyer, J.S. \& Pieterse, H.J.C., 2010. 'Religion in the public sphere: What can public theology learn from Habermas's latest work?', HTS Teologiese Studies/Theological Studies 66(1), Art. \# 798, 1-7. https://doi.org/10.4102/hts.v66i1.798

Dreyer, Y., 2004, 'A public practical theological theory for religious education of secularised youth', HTS 60(3), 919-945. https://doi.org/10.4102/hts.v60i3.615

Essays, UK, 2013, Sociological perspectives of family and household, viewed n.d., from http://www.ukessays.com/essays/sociology/sociological-perspectives-of-familyand-household. php?vref $=1$

Gathogo, J., 2007, 'African theology of reconstruction as a practical theology for all', Practical Theology in South Africa 24(2), 99-121.

Gifford, P., 2008, 'Africa's inculturation theology: Observations of an outsider', Hekima Review 38, 18-34.

Hajnal, J., 1982, 'Two kinds of preindustrial household formation system', Population Development 8, 449-494. https://doi.org/10.2307/1972376

Haralambos, M. \& Holborn, M., 2004, Sociology :Themes and perspectives, Harper Collins, London.

Jackson, J., 1997, Migration and urbanization in the Ruhr Valley, Humanities Press, Boston, MA.

Janssens, A.,1993, Family and social change. The household as process in an industrializing community, University Press Cambridge, Cambridge.

Kertzer, D. \& Hogan, D., 1989, Family, political economy, and demographic change. The transformation of life in Casalecchio, Italy, 1861-1921, The University of Wisconsin Press, Madison.

Koppel, M.S., 2015, 'Practicing public pastoral theologies in contexts of difference', Journal of Pastoral Theology 25(3), 151-152. https://doi.org/10.1080/10649867. 2015.1123923

Laslett, P., 1969, 'Size and structure of the household in England over three centuries', Population Studies 23, 199-223. https://doi.org/10.1080/00324728. 1969.10405278

Le Play, F., 1855, Les ouvriers Europe'ens: L'organisation des familles [European laborers: The organization of families], Imprimerie imperiale, Paris.

Le Play, F., 1872, The organization of labor, Claxton, Remsen \& Haffelfinger, Philadelphia, PA.

Liang, Z., 2008, 'The sociology of migration', in C. Bryant \& D. Peck (Eds.), 21st century sociology, Sage Publications, Thousand Oaks, CA

Louw, D.J., 2008, Cura Vitae: Illness and the healing of life in pastoral care and counselling, Lux Verbi, Cape Town.

Louw, D.J., 2014, Wholeness in hope care on nurturing the beauty of the Human soul in spiritual healing, LIT, Wien.
Magezi, V., 2006, 'Community healing and the role of pastoral care of the ill and suffering in Africa', In die Skriflig 40(3), 505-521. https://doi.org/10.4102/ids. v40i3.356

Magezi, V., 2016a, 'Pastoral care within globalisation care at the in-between: The dynamics of pastoral care and counselling for meaning and Coping in a global context', in U. Elsdörfer \& T.K. Ito (eds.), Compassion for one another in the Global village: Social and cultural approaches to care and counselling, pp. 65-78, LIT VERLAG Gmbh \& Co. KG Wien, Klosbachstr.

Magezi, V., 2016b, 'Reflection on pastoral care in Africa: Towards discerning emerging pragmatic pastoral ministerial responses', In die Skriflig 50(1), a2130. https://doi. org/10.4102/ids.v50i1.2130

Magezi, V., 2017, 'Ubuntu in flames - Injustice and disillusionment in post-colonial Africa: A practical theology for new "liminal Ubuntu" and personhood" in J. Dreyer, Y. Dreyer, E. Foley \& M. Nel (eds.), Practicing Ubuntu: Practical theological persf (Series: International Practical Theology), LIT VERLAG GmbH \& Co. KG, Wien.

Mbiti, J., 1969, African religions and philosophy, Heinemann, London.

Miller-McLemore, B.J., 2005, 'Pastoral theology and public theology', in E. Graham \& A. Rowlands (eds.), Pathways to the public square, pp. 95-106, Transaction Publishers, London.

Osmer, R. \& Schweitzer, F., 2003, Religious education between modernization and globalization: New perspectives on the United States and Germany, Eerdmans, Grand Rapids, MI.

Puschmann, P. \& Solli, A., 2014, 'Household and family during urbanization and industrialization: Efforts to shed new light on an old debate', The History of the Family 19(1), 1-12. https://doi.org/10.1080/1081602X.2013.871570

Ruggles, S., 2012, 'The future of historical family demography', Annual Review of Sociology 38, 423-441. https://doi.org/10.1146/annurev-soc-071811-145533

Russell, M., 2003, 'Are urban Black families nuclear? A comparative study of Black and White South African family norms', Social Dynamics 29(2), 153-176. https://doi. org/10.1080/02533950308628679

Ssemogerere, G.N., 2011, Cultural and social situation of the family today an African perspective with particular reference to Uganda, viewed n.d., from http://www. familiam.org/pcpf/allegati/1158/Intervento_Ssemogerere.pdf

Vanhoozer, K.J. \& Strachan, O., 2015, The Pastor as Public Theologian, Baker Academic, MI.

Thornton, A., 2005, 'Frederick Le Play, the developmental paradigm, reading history sideways, and family myths', Working paper of the Population Studies Center, University of Michigan.

Wasike, A.N. \& Waruta, D.W. (ed.), 2000, Mission African Christianity: Critical essays in missiology, Acton Press, Nairobi.

Waruta, D.W. \& Kinoti, H.K., 1994, Pastoral care in African Christianity, Acton Press, Nairobi. 